\title{
Entry Requirements as Predictors of the Academic Performance of Postgraduate Students in Universities in Zimbabwe
}

\author{
Norman Rudhumbu* ${ }^{*}$ and Patience Kelebogile Mudau \\ College of Education, University of South Africa, Pretoria, South Africa
}

\begin{abstract}
One of the major strategies that universities use to ensure quality in education is the use of entry requirements as a screening procedure to ensure that only those considered to be the 'best' students are admitted. Whether these so-called 'best' students eventually perform to expectations academically is an issue on which conclusive evidence does not exist. Also, recruiting students with high entry requirements is viewed in universities as a confidence-building exercise with regard to the quality of graduates churned out by educational institutions. This study, therefore, examined whether a significant relationship exists between entry requirements and the academic performance of postgraduate students admitted into universities in Zimbabwe based on different entry qualifications. The study used a descriptive research design that employed a quantitative approach located in the post-positivist paradigm. A sample of 110 Master of Education in Mathematics (M.Ed $\mathrm{MT}_{\mathrm{MT}}$ ) students admitted into the programme based on the Bachelor of Education (B.Ed.) and the Bachelor of Science Education (BScEd) degrees was randomly selected from a population of $200 \mathrm{M}$.Ed $\mathrm{d}_{\mathrm{MT}}$ students from four universities in Zimbabwe. The t-test and ANOVA were used to analyse the data. The study revealed that degree classifications at the undergraduate level had no significant influence on the academic performance of postgraduate students. It was also concluded that there were no significant differences in the academic performance of students admitted into the M.Ed ${ }_{\text {MT }}$ programme based on the B.Ed. and BScEd degrees.
\end{abstract}

Keywords: academic performance; degree classifications; entry requirements; postgraduate students; university students; universities

\section{Introduction and background}

The recruitment of students by means of high university or programme entry requirements may be critical for ensuring that university education achieves its mandate (Haj et al., 2018). Entry requirements are used to filter and screen

\footnotetext{
* Corresponding author: Norman Rudhumbu; nrudhumbu@buse.ac.zW
} 
students so that universities admit only those students they consider the best, and who have a better chance of progressing and succeeding in their studies (Haj et al., 2018). According to Haj et al. (2018, p. 3), entry requirements refer to "a process of matching, guidance and selection that enables students to access university education at the different levels". From the above definitions, it can be concluded that entry requirements represent the single most important indicators of students' future successful handling of the intellectual rigours of particular programmes in an educational institution. In the context of Zimbabwean universities, undergraduate students with either distinctions or 2.1-degree classes have a higher likelihood of being admitted into postgraduate studies than those with lower entry qualifications. Also, such students are deemed to have a better chance of successfully completing their studies when compared with those with weaker passes. This further shows that these entry requirements may be important in predicting a student's current readiness and future ability to progress in academic programmes offered by an educational institution.

The current study sought to establish whether entry requirements have a significant influence on the academic performance of postgraduate (master's students). An entry requirement for prospective students to postgraduate programmes in Zimbabwe is a good undergraduate degree in a relevant area of specialisation. A good degree is one that has a high degree classification such as either a distinction, merit or credit classification in the area of specialisation. In this study, an education-related undergraduate degree is considered to be an entry requirement for education-related postgraduate studies (University of Zimbabwe, 2021; Bindura University of Science Education, 2021; Great Zimbabwe University, 2021). Only 22 universities in Zimbabwe are mandated to train teachers and lecturers in education (Ministry of Higher and Tertiary Education, Innovation, Science and Technology Development, 2021). Of the 22 universities, 20 train students in the Master of Education (M.Ed.) degree specialising in mathematics, while the remaining two universities train teachers and lecturers in science education.

For a student to be admitted to an M.Ed. degree, he or she should have either a good pass in either a Bachelor of Science Education degree (BScEd) or a Bachelor of Education degree (B.Ed.) in their areas of specialisation (Bindura University of Science Education, 2021; University of Zimbabwe, 2021; Great Zimbabwe University, 2021). Degree classification is used as a means to show whether a degree is a good degree or not. Undergraduate and postgraduate degree classifications at universities in Zimbabwe are as shown in Table 1 while postgraduate degree classifications are as shown in Table 2 (University of Zimbabwe, 2021; Great Zimbabwe University, 2021).

Table 1: Undergraduate degree classifications

\begin{tabular}{lcc}
\hline Degree class & Mark range & Description \\
\hline 1 & $75-100 \%$ & Distinction (D) \\
2.1 & $65-74 \%$ & Merit (M) \\
2.2 & $60-64 \%$ & Credit (C) \\
3 & $50-59 \%$ & Pass (P) \\
F & 49 and below & Fail (F) \\
\hline
\end{tabular}

Source: Bindura University of Science Education (2021) 
Table 2: Postgraduate degree classifications

\begin{tabular}{lcc}
\hline Degree class & Mark range & Description \\
\hline 1 & $80-100 \%$ & Distinction (D) \\
2.1 & $70-79 \%$ & Merit (M) \\
2.2 & $60-69 \%$ & Credit (C) \\
3 & $50-59 \%$ & Pass (P) \\
F & 49 and below & Fail (F) \\
\hline
\end{tabular}

Source: Bindura University of Science Education (2021)

The important consideration regarding the differences between the degree classification scales in Tables 1 and 2 is the point at which a distinction is conferred to a student. For postgraduate students, a distinction is conferred when the overall mark is at least $80 \%$, while for undergraduate students the conferment of distinction status is $75 \%$ and upwards. This was decided because postgraduate students are mature students who are expected to have had more time than the undergraduate students to acclimatise to the pressures of institutional social and academic environments, hence are expected to perform at higher levels than the undergraduate students (Bindura University of Science Education, 2021).

Various studies have sought to establish whether there are any significant academic performance differences between students admitted to undergraduate programmes based on different entry requirements (Abdulkadir, Onibere \& Odion, 2019; Murray, 2017). Not much research, however, has been conducted to establish whether entry requirements have an effect on the academic performance of students admitted into postgraduate programmes, based on different academic admission requirements. It is in this context that this study wished to establish whether there were significant differences between the academic performance of students admitted to the M.Ed $\mathrm{MT}_{\mathrm{MT}}$ degree programme based on B.Ed. and BScEd degrees. These findings could have implications for both policy and practice with regard to the admission of students to university postgraduate programmes.

\section{Research questions}

1. Is there any significant difference between entry requirements and the academic performance of postgraduate students?

2. To what extent do undergraduate degree classifications contribute to the academic performance of postgraduate students?

\section{Literature review: Conceptual and theoretical frameworks}

In this section, the concept of academic performance is discussed, as well as the theory that was used as a theoretical lens for the study.

\subsection{Conceptualising academic performance}

There have been a multiplicity of debates and discussions on the relationship between entry requirements and the academic performance of students in universities (Murray, 2017). It is necessary to link entry requirements to academic performance because academic performance relates to that which manifests itself through knowledge, skills, attitudes and understanding of ideas, which can be defined as students' ability to demonstrate mastery of what has been taught and learnt (Wambugu \& Emeke, 2016). Abdulkadir et al. (2019) also define academic 
performance as knowledge attained or skills developed in school subjects as reflected by test scores assigned by teachers. Based on the above definitions and as explained by Odukoya, Adekeye, Atayero, Omole et al. (2018), academic performance acts as a yardstick for the confirmation of the competencies of students after a learning experience. It can also be argued, from the above definitions, that academic performance is a demonstration of the abilities and skills of students after a learning session. In other words, and based on the above definitions, academic performance is what a student is able to do after going through some learning, as measured by scores in either a formative or summative assessment.

\subsection{Relationship between student entry requirements and academic performance}

The connection between entry requirements and academic performance has been studied broadly and results suggest that academic performance can be affected by a number of factors, among which is students' entry requirements (Abdulhadir \& Ogwueleka, 2019; Haj et al., 2018; Wambugu \& Emeke, 2016). A study by Syed (Sulphey, AlKahtani \& Syed, 2018) found a positive correlation between entry qualifications and the academic performance of students admitted into universities based on different entry requirements and further found that sciencebased students performed better than non-science-based students. A number of other studies also found significant relationships between academic performance and admission requirements (Aciro, Onen, Malinga, Ezati \& Openjuru, 2021; Adamu, Anza \& Hananiya, 2019; Brook \& Roberts, 2021; Olubusayo, 2021). A strong relationship between entry requirements and the academic performance of students was also confirmed in studies by Alamoudi et al. (2021), Kurlaender and Cohen (2019); Abdullah and Mizra (2018), and Ferrão and Almeida (2019), which established that students with, for example, an A grade as either their preuniversity or pre-programme entry qualification had a very high likelihood of not only attaining high grades in their studies but also of completing their studies.

Other studies, however, found no significant academic performance differences between students admitted to university programmes based on different entry requirements. This was confirmed in studies by Abdulkadir et al. (2019) and Queensoap, Arogo, Dogitimiye, Williams and Maxwell (2017), who found no significant relationships between entry requirements and differences between the academic performances of students admitted to university programmes based on different entry requirements. The above results were confirmed in a study by Mutiso and Muthama (2019), who found that entry results did not have a strong effect on the academic performance of students.

The above results, therefore, demonstrate that there is no conclusive evidence of the relationship between entry requirements and the academic performance of students. While some studies suggest that there is a strong relationship, others claim that there is no significant relationship between entry requirements and the academic performance of students. This shows that the relationship between entry requirements and academic performance is still an area needing further research as there might be other variables, besides entry requirements, that may be contributory to the nature of the academic performance of students. For example, 
differences in the academic performance of students with different entry qualifications could be a result of factors such as teaching environment and quality of teaching, class size, the age and the gender of students. Other factors that may also affect the link between entry qualifications and academic performance could be that the university where the student has done his or her undergraduate studies may not have had adequate resources, hence affecting the quality of the entry qualifications of the student. However, when admitted to a university with adequate resources, such a student may perform much better than those students with higher entry qualifications.

The effect of undergraduate degree classifications in the academic performance of postgraduate students has been discussed extensively as potentially contributing to the academic performance of postgraduate students (Putpuek, Rojanaprasert, Atchariyachanvanich \& Thamrongthanyawong, 2018). Various studies found a significant relationship between the academic performance of students and degree classifications at entry level. Studies by Tatar and Düstegör (2020), Shahiri, Husain and Rashid (2017), and Putpuek et al. (2018) established that degree classification had a significant effect on the performance of students in their programmes of study.

As was the case with entry requirements, the lack of conclusive evidence on whether degree classifications contribute to differences in academic performance among students shows that there could be other factors related to degree classifications that contribute to the differences, if any, in the academic performance of students with different degree classifications. For example, one critical issue is that end of the semester (EOS) and end of course (EOP) examinations are internally set and administered by universities without going through the rigours of reliability and validity testing, as well as checking whether the items used in the assessments comply with the levels of Bloom's taxonomy. Without this rigour, this may mean that accurately measuring the performance of students according to the different degree classifications may not be as accurate as required, resulting in students who might have qualified for a distinction, failing to get one, or those who do not deserve to get distinctions, getting them. This could be a serious problem in measuring students' pre-programme admissions, using degree classifications. Another issue could also be that universities in Zimbabwe show vast differences concerning teaching and learning resources - from the quality of staff and teaching to the adequacy of teaching and learning resources. Undergraduate students from poorly resourced institutions may have lower degree classifications when compared to those from highly resourced universities, where even brilliant students fail to get distinctions in their studies.

\subsection{Theoretical framework}

For this study, the Student Integration Model (SIM), developed by Tinto (1997), was employed as a theoretical lens guiding the study. The SIM is one of the most used models to explain the relationship between student academic performance and pre-university entry attributes of students. Based on the degree of fit between a student and the institutional environment, the model links either the pre- 
university or pre-programme entry attributes of a student to the educational outcomes (Schreiber, Luescher-Mamashela \& Moja, 2014). It is a model that is premised on the assumption that students enter colleges and universities, or enrol for programmes for further education with a range of background traits such as academic aptitude, pre-university achievement, socio-economic background, cultural backgrounds and others that have an effect on the extent to which they positively integrate with the academic and social environments of an institution and the extent to which they will perform academically (Arnekrans, 2014). The main purpose of the SIM is to explain how a student's pre-university attributes help to shape his or her interactions with the institutional environment, as well as how such interactions impact the student's academic performance (Arnekrans, 2014). In the context of this study, the SIM helps to explain how pre-postgraduate programme admission attributes of students (undergraduate degree classifications and type of degree programme) influence their academic performance at the postgraduate level. Based on the conceptual and theoretical frameworks, a research model (Figure 1) was developed and a number of hypotheses were formulated.

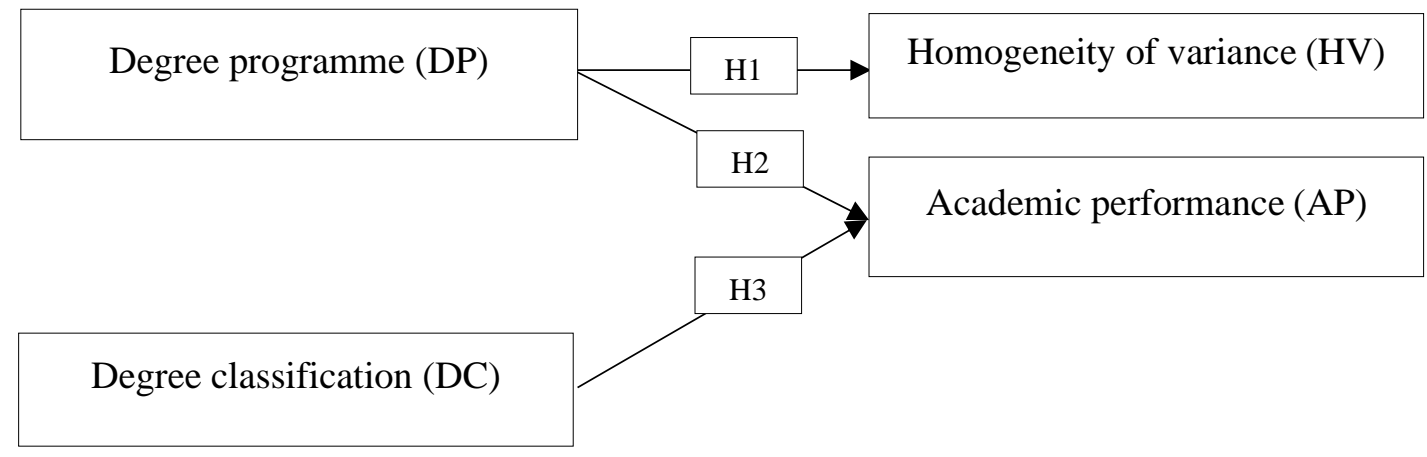

Figure 1: Research model

H1: There is a significant homogeneity of variance difference in the academic performance of students admitted into the M.Ed $d_{M T}$ programme based on the B.Ed. and the BScEd. degrees respectively.

H2: There are significant differences in the academic performance of students enrolled in an M.Ed $d_{M T}$ programme based on the B.Ed. and BScEd. degrees respectively.

H3: There are significant differences in the academic performance of M.Ed $d_{M T}$ students according to degree classification.

\section{Research methodology}

In this section, the research design, research paradigm, research approach, sampling procedures, and methods of data collection and analysis are discussed.

\subsection{Research design and sampling}

An ex-post-facto research design and a quantitative approach located in the postpositivist paradigm were used for the study, and a retrospective cohort analysis strategy was employed. The ex-post-facto research design, also called the afterthe effect-research design, is a quasi-experimental design in which groups with qualities that already exist are studied in order to understand the current state of a phenomenon under research (Sharma, 2019; Watson, 2012). By definition, a 
retrospective cohort analysis uses existing data that are kept as records for reasons other than research, to explain or understand a current or future situation (Wang \& Kattan, 2020). In this study, an ex-post-facto design was used to establish whether there were any differences in the academic performance of students who were admitted to the M.Ed $\mathrm{M}_{\mathrm{MT}}$ programme based on B.Ed. and BScEd. degrees respectively.

The population for the study consisted of 200 M.Ed. students at four universities in the 2020 second semester of their academic year of study; thus, a multiple case study was used. The four universities were purposively selected owing to their close proximity to the researcher as a strategy for mitigating the challenge of travelling long distances to collect data during the COVID-19 period. The four universities are located in two nearby towns in Zimbabwe. A sample of 110 students from the M.Ed. mathematics programme was used for the study. The sample size was determined using the sample size table developed by the Research Advisors (2006) at a 95\% level of confidence and a 7.5\% margin of error. The sample was selected using the stratified random sampling strategy in classes already constituted to ensure that a proportionate number of B.Ed. and BScEd students would participate in the study since academic records showed that there were more students admitted based on the B.Ed. degree than those with the BScEd degree at the four universities. Using the sampling strategy explained above, and based on the sample size, the researchers proportionately selected the two samples (cf. Creswell, 2015) from the 200 students to make up the final study sample of 110 students. As a result, the study sample comprised more B.Ed. students than BScEd students. From the total sample of 110, the B.Ed. students counted 60 and 50 were BScEd students. These students studied the following courses in the semester under consideration: Entrepreneurship Education (EN), Operations Research (OP), Numerical Methods for Partial Differential Equations (NM), Advanced Numerical Methods (AN), Functional Analysis (FN) and Educational Management and Leadership (EM).

\subsection{Data collection}

Data for the study were collected from academic records of the 2020 second semester at the four universities. The data were collected without any direct, rigorous manipulation and control as per the requirements of the retrospective cohort analysis strategy (Kpolovie, 2020). The researchers designed and used an entry-qualifications academic performance inventory to collect data on admissions and EOS (end of the semester) examination results from the academic records of the four universities.

\subsection{Data analysis}

Descriptive statistics that included percentages, mean and standard deviations were used for summarising data. Correlation analysis was used for establishing the strength and magnitude of relationships between variables. One-way ANOVA was used to establish whether there was a significant relationship between the academic performance of $\mathrm{M} \cdot \mathrm{Ed}_{\mathrm{MT}}$ students and their degree classifications. An independent t-test was used to determine whether there were significant differences in the academic performance of students admitted into the M.Ed ${ }_{\text {MT }}$ programme ensuing from the B.Ed. and the BScEd degrees respectively. 
The f-tests using Hartley's F-max test for homogeneity of group variances were used for establishing whether there was any significant difference between the homogeneity of the variance in the academic performance of students admitted to the M.Ed $\mathrm{d}_{\mathrm{MT}}$ programme following on the B.Ed. and BScEd degrees.

\subsection{Ethical considerations}

Ethical considerations were adhered to. Respondents were assured of anonymity and participation was voluntary. Respondents also signed consent forms before participating in the study. The study was approved by the institutions involved.

\subsection{Data validation}

The reliability and validity of the F-test and t-test results for the six $M . E d_{M T}$ courses were assessed using the test of data normality, as well as the Hartley's Fmax test of homogeneity of their variances (Ihiegbulem, 1992).

\section{Results}

In this section the data analysis procedures are reported on, namely the entry requirements used by students, data normality assessment, assessment of the relationship between degree classification and academic performance, assessment of the relationship between the type of degree and academic performance, as well as validation of the F-test and t-test results using Hartley's F- max test for homogeneity of group variances.

\subsection{Data normality test}

The assessment of data normality for the entry requirements and academic performance measurements in the study was conducted using the Shapiro-Wilk test, z-scores, the observation of normal Q-Q plots (Field et al., 2012; Janssens et al., 2008; Shapiro and Wilk, 1965), and Hartley's F-max test of homogeneity (Glen, 2016; Phillips, 1982). The results of the assessment showed that data were normally distributed as demonstrated by the Shapiro-Wilk values which were not significant ( $p$ > .05) (Janssens et al., 2008; Shapiro and Wilk, 1965), z-score values which ranged between -1.645 and +1.645 (Field et al., 2012), and all the data points being within the diagonal lines of their respective normal Q-Q plots (Field et al., 2012).

To test whether the spread (variance) of the data was similar across groups and to determine whether or not the calculated F-values and t-values would be reliable, Hartley's F-max test was used (Glen, 2016; Phillips, 1982).

Table 3: Hartley's F- max test for homogeneity of group variances

\begin{tabular}{llccccc}
\hline $\begin{array}{l}\text { Course of } \\
\text { study }\end{array}$ & $\begin{array}{l}\text { Entry } \\
\text { qualification }\end{array}$ & $\mathbf{N}$ & $\mathbf{S D}$ & $\begin{array}{c}\text { Variance } \\
\left(\mathbf{S}^{2}\right)\end{array}$ & $\begin{array}{c}\text { fcalc- } \\
\text { value }\end{array}$ & Decision \\
\hline EN & B.Ed $_{\mathrm{MT}}$ & 60 & 6.41 & 41.088 & 1.152 & Not Supported \\
& BScEd $_{\mathrm{MT}}$ & 50 & 6.88 & 47.334 & & \\
$\mathrm{OP}$ & B.Ed $_{\mathrm{MT}}$ & 60 & 10.16 & 103.226 & 1.272 & Not Supported \\
& BScEd $_{\mathrm{MT}}$ & 50 & 11.46 & 131.332 & & \\
$\mathrm{NM}$ & B.Ed $_{\mathrm{MT}}$ & 60 & 8.55 & 73.103 & 1.059 & Not Supported \\
& BScEd $_{\mathrm{MT}}$ & 50 & 8.31 & 69.056 & & \\
$\mathrm{AN}$ & B.Ed & 60 & 11.38 & 129.504 & 1.402 & Not Supported
\end{tabular}




\begin{tabular}{lllcccl} 
& BScEd $_{\text {MT }}$ & 50 & 9.61 & 92.352 & & \\
FN & B.Ed $_{\text {MT }}$ & 60 & 10.27 & 105.473 & 1.213 & Not Supported \\
& BScEd $_{\text {MT }}$ & 50 & 11.31 & 127.916 & & \\
EM & B.Ed & & \\
& B.Ed & 60 & 9.51 & 90.440 & 1.238 & Not Supported \\
& B.Ed $_{\text {MT }}$ & 50 & 10.58 & 111.936 & & \\
\hline
\end{tabular}

Notes: Expected f-value $=1.84 ;$ Numerator $=59 ;$ Denominator $=49 ;$ fcalc - Calculated $f$-value

The results of the F-max test depicted in Table 3 showed that for all M.Ed. courses, EN(fcalc-value (1.152) < expected f-value [1.84]), OP(fcalc-value $(1.272)<$ expected f-value (1.84), NM (fcalc-value (1.059) < expected f-value [1.84]), AN (fcalc-value (1.402) < expected f-value [1.84]), FN (fcalc-value (1.213) < expected f-value [1.84]), and EM (calcf-value (1.238) < expected f-value [1.84]), demonstrating that the spread of the data was homogenous across all M.Ed. courses and that the calculated F-values and t-values would be reliable (cf. Glen, 2016; Phillips, 1982).

\subsection{Record of entries into M.Ed. programme}

The results in Table 4 provide information on the records of students admitted to the M.Ed $\mathrm{d}_{\mathrm{MT}}$ programme at the four universities, based on the different entry requirements.

Table 4: Students admitted to the M.Ed $\mathrm{M}_{\mathrm{MT}}$ programme at the 4 universities based on the different entry qualifications $(n=110)$

\begin{tabular}{cccc}
\hline Entry degree & Degree class & No. of students & $\%$ \\
\hline B.Ed. & 1 & 17 & 15 \\
& 2.1 & 15 & 14 \\
& 2.2 & 21 & 19 \\
BScEd & 3 & 7 & 6 \\
& 1 & 10 & 9 \\
& 2.1 & 25 & 23 \\
& 2.2 & 10 & 9 \\
Total & 3 & 5 & 5 \\
\hline
\end{tabular}

Notes: M.Ed $d_{M T}-M . E d$. Mathematics specialisation; Undergraduate degree classification: 1: 80-100\%; 2.1: 70-79\%; 2.2: 60-69\%; 3: 50-59\%; F: 0-49\%; F- Fail

According to Table 4, of the 110 students who were admitted to the M.Ed $\mathrm{MT}_{\mathrm{MT}}$ programme, $24 \%$ were admitted with first-class degrees or distinctions $(15 \%$ in B.Ed. and $9 \%$ in BScEd), $37 \%$ had Merits (14\% in B.Ed. and $23 \%$ in BScEd), $28 \%$ had Credits (19\% in B.Ed. and 9\% in BScEd) and $11 \%$ had a Pass $(6 \%$ in B.Ed. and $5 \%$ in BScEd). This showed that overall, the M.Ed. students were fairly good academic performers at entry point.

Table 5 depicts the analysis of the academic performance using group mean scores of M.Ed $\mathrm{MT}_{\mathrm{T}}$ students in EOS examinations according to entry degree class. 
Table 5: Academic performance using group mean scores in M.Ed $\mathrm{d}_{\mathrm{MT}}$ EOS examinations according to degree class

\begin{tabular}{|c|c|c|c|c|c|c|c|c|c|}
\hline $\begin{array}{l}\text { M.Ed. } \\
\text { Course }\end{array}$ & $\begin{array}{l}\text { Entry } \\
\text { degree }\end{array}$ & $\begin{array}{c}\text { Degree } \\
\text { class }\end{array}$ & $\begin{array}{c}\text { No. of } \\
\text { students }\end{array}$ & $\begin{array}{l}\text { Total } \\
\text { score }\end{array}$ & $\mathbf{M}_{1}$ & $\mathbf{M}_{2}$ & Min mark & Max mark & SD \\
\hline \multirow[t]{4}{*}{ EN } & B.Ed. & 1 & 17 & 1300 & 76.47 & \multirow{4}{*}{69.76} & \multirow{4}{*}{57} & \multirow{4}{*}{81} & 6.13 \\
\hline & & 2.1 & 15 & 1035 & 68.98 & & & & 6.51 \\
\hline & & 2.2 & 21 & 1411 & 67.18 & & & & 7.04 \\
\hline & & 3 & 7 & 465 & 66.41 & & & & 10.53 \\
\hline \multirow[t]{4}{*}{ EN } & BScEd & 1 & 10 & 766 & 76.61 & \multirow{4}{*}{69.19} & \multirow{3}{*}{68} & \multirow{4}{*}{85} & 7.19 \\
\hline & & 2.1 & 25 & 1733 & 69.33 & & & & 7.54 \\
\hline & & 2.2 & 10 & 645 & 64.51 & & & & 9.27 \\
\hline & B.Ed. & 3 & 5 & 331 & 66.29 & & & & 9.50 \\
\hline \multirow[t]{4}{*}{ OP } & & 1 & 17 & 1235 & 72.66 & \multirow{4}{*}{66.63} & \multirow{4}{*}{54} & \multirow{4}{*}{74} & 9.11 \\
\hline & & 2.1 & 21 & 1434 & 68.30 & & & & 10.42 \\
\hline & & 2.2 & 15 & 1354 & 64.47 & & & & 9.57 \\
\hline & $\mathrm{BScEd}$ & 3 & 7 & 428 & 61.09 & & & & 6.51 \\
\hline \multirow[t]{4}{*}{$\mathrm{OP}$} & & 1 & 10 & 709 & 70.89 & \multirow{4}{*}{66.86} & \multirow{4}{*}{51} & \multirow{4}{*}{73} & 10.26 \\
\hline & & 2.1 & 25 & 1696 & 67.83 & & & & 10.05 \\
\hline & & 2.2 & 10 & 653 & 65.28 & & & & 9.27 \\
\hline & B.Ed. & 3 & 5 & 317 & 63.44 & & & & 9.61 \\
\hline \multirow[t]{4}{*}{ NM } & & 1 & 17 & 1161 & 68.28 & \multirow{4}{*}{64.47} & \multirow{4}{*}{51} & \multirow{4}{*}{77} & 9.16 \\
\hline & & 2.1 & 15 & 977 & 65.13 & & & & 9.62 \\
\hline & & 2.2 & 21 & 1352 & 64.36 & & & & 7.54 \\
\hline & BScEd & 3 & 7 & 421 & 60.12 & & & & 10.81 \\
\hline NM & & 1 & 10 & 675 & 67.53 & & & & 8.69 \\
\hline & & 2.1 & 25 & 1623 & 64.92 & & & & 10.14 \\
\hline & & 2.2 & 10 & 625 & 62.47 & 63.66 & 53 & 79 & 8.73 \\
\hline & B.Ed. & 3 & 5 & 299 & 59.81 & & & & 9.55 \\
\hline AN & & 1 & 17 & 1177 & 69.25 & & & & 10.88 \\
\hline & & 2.1 & 15 & 1026 & 68.41 & & & & 9.15 \\
\hline & & 2.2 & 21 & 1375 & 65.48 & 66.03 & 60 & 81 & 11.17 \\
\hline & BScEd & 3 & 7 & 427 & 60.99 & & & & 10.51 \\
\hline AN & & 1 & 10 & 695 & 69.46 & & & & 11.32 \\
\hline & & 2.1 & 25 & 1659 & 66.35 & & & & 9.69 \\
\hline & & 2.2 & 10 & 672 & 67.19 & 66.63 & 61 & 84 & 10.17 \\
\hline & $\mathrm{D} \Gamma \mathrm{d}$ & 3 & 5 & 318 & 63.52 & & & & 10.33 \\
\hline FN & B.EA. & 1 & 17 & 1111 & 65.33 & & & & 10.56 \\
\hline & & 2.1 & 15 & 906 & 60.42 & & & & 9.71 \\
\hline & & 2.2 & 21 & 1395 & 66.44 & 63.87 & 47 & 69 & 10.28 \\
\hline & BScEd & 3 & 7 & 443 & 63.30 & & & & 10.58 \\
\hline FN & & 1 & 10 & 637 & 63.69 & & & & 7.53 \\
\hline & & 2.1 & 25 & 1587 & 63.47 & & & & 7.41 \\
\hline & & 2.2 & 10 & 666 & 66.55 & 64.17 & 49 & 79 & 9.44 \\
\hline & B.Ed. & 3 & 5 & 315 & 62.95 & & & & 9.03 \\
\hline EM & & 1 & 17 & 1278 & 75.15 & & & & 9.57 \\
\hline & & 2.1 & 15 & 1071 & 71.42 & 7006 & & & 10.13 \\
\hline & & 2.2 & 21 & 1392 & 66.31 & 70.06 & 63 & 90 & 10.35 \\
\hline & & 3 & 7 & 448 & 67.34 & & & & 9.69 \\
\hline EM & $\mathrm{BScEd}$ & 1 & 10 & 757 & 75.66 & & & & 6.84 \\
\hline & & 2.1 & 25 & 1753 & 70.12 & & & & 7.11 \\
\hline & & 2.2 & 10 & 768 & 66.81 & 69.55 & 61 & 91 & 6.53 \\
\hline & & 3 & 5 & 328 & 65.59 & & & & 6.88 \\
\hline
\end{tabular}

Notes: $M_{1}-$ Group mean scores by degree class per course; $M_{2}$ - Overall group mean score per course; EN Entrepreneurship Education; OP _ Operations Research; NM - Numerical Methods for Partial Differential Equations; AN - Advanced Numerical Methods; FN - Functional Analysis; EM - Educational Management and Leadership; $M$ - Mean score; SD - Standard deviation 
The results given in Table 5 show the academic performance of students in the M.Ed $\mathrm{dT}_{\mathrm{MT}}$ programme during the EOS examinations per entry degree, per course and per degree class. The results also show the lowest and highest scores achieved by students in each course. In terms of differences in group mean scores per course (M1) according to B.Ed. and BScEd degree classifications of students admitted to the $\mathrm{M} . E \mathrm{~d}_{\mathrm{MT}}$ degree programme, the results in Table 3 further show that the group mean score per course ranged between 14 and 1.77 for distinction students, 21 and 3.05 for merit students, 11 and 2.67 for credit students, and 12 and 2.53 for pass students. With regard to the differences in the overall group mean scores per course $\left(\mathrm{M}_{2}\right)$ in the courses to which students were admitted from the B.Ed. and BScEd degrees, the overall group mean score differences per course were 57 for EN; 23 for OP; 81 for NM; 60 for AN; 30 for FN; and 51 for EM. These figures show that the overall group mean score differences ranged from 23 to 81, indicating in turn that there were small differences in the EOS (end of the semester) academic performance of students admitted to the M.Ed $\mathrm{MT}_{\mathrm{MT}}$ programme from the B.Ed. and BScEd degree programmes.

\subsection{Hypotheses testing}

Table 6 shows the inter-construct correlations among the independent variables, as well as whether there were significant relationships between the independent variables and the dependent variable.

Table 6: Inter-construct correlation metrics for the entry requirements and academic performance in M.Ed $\mathrm{d}_{\mathrm{MT}}$ EOS examinations

\begin{tabular}{|c|c|c|c|c|c|c|c|c|c|c|c|c|c|}
\hline $\begin{array}{l}\text { Const } \\
\text { ructs }\end{array}$ & $\mathrm{AP}$ & $\begin{array}{l}\text { B.Ed } \\
\text { EN }\end{array}$ & $\begin{array}{l}\text { B.Ed } \\
\text { OP }\end{array}$ & $\begin{array}{l}\text { B.Ed } \\
\text { NM }\end{array}$ & $\begin{array}{l}\text { B.Ed } \\
\text { AN }\end{array}$ & $\begin{array}{l}\text { B.Ed } \\
\text { FN }\end{array}$ & $\begin{array}{l}\text { B.Ed } \\
\text { EM }\end{array}$ & $\begin{array}{l}\mathrm{BScE} \\
\mathrm{dEN}\end{array}$ & $\begin{array}{l}\text { BScE } \\
\text { dOP }\end{array}$ & $\begin{array}{l}\mathrm{BScE} \\
\mathrm{dN} \\
\mathrm{M}\end{array}$ & $\begin{array}{l}\text { BScEd } \\
\text { AN }\end{array}$ & $\begin{array}{l}\mathrm{BScE} \\
\mathrm{dFN}\end{array}$ & $\begin{array}{l}\mathrm{BScE} \\
\mathrm{dEM}\end{array}$ \\
\hline $\mathrm{AP}$ & 1.00 & & & & & & & & & & & & \\
\hline $\begin{array}{l}\text { B.EdE } \\
\mathrm{N}\end{array}$ & .454 & 1.000 & & & & & & & & & & & \\
\hline $\begin{array}{l}\text { B.Ed } \\
\text { OP }\end{array}$ & .341 & .338 & 1.000 & & & & & & & & & & \\
\hline $\begin{array}{l}\text { B.Ed } \\
\text { NM }\end{array}$ & .351 & .373 & .117 & 1.000 & & & & & & & & & \\
\hline $\begin{array}{l}\text { B.Ed } \\
\text { AN }\end{array}$ & .209 & .354 & .085 & .133 & 1.000 & & & & & & & & \\
\hline $\begin{array}{l}\text { B.EdF } \\
\mathrm{N}\end{array}$ & .217 & .319 & .041 & .044 & .081 & 1.000 & & & & & & & \\
\hline $\begin{array}{l}\text { B.EdE } \\
\text { M }\end{array}$ & .302 & .228 & .064 & .053 & .038 & .037 & 1.000 & & & & & & \\
\hline $\begin{array}{l}\text { BScE } \\
\text { dEN }\end{array}$ & .473 & .995 & .091 & .097 & .138 & .052 & .037 & 1.000 & & & & & \\
\hline $\begin{array}{l}\text { BScE } \\
\text { dOP }\end{array}$ & .342 & .301 & .902 & .059 & .051 & .033 & .059 & .217 & 1.000 & & & & \\
\hline $\begin{array}{l}\mathrm{BScE} \\
\mathrm{dNM}\end{array}$ & .346 & .361 & .075 & .971 & .044 & .031 & .061 & .259 & .073 & 1.000 & & & \\
\hline $\begin{array}{l}\text { BScE } \\
\text { dAN }\end{array}$ & .207 & .361 & .112 & .065 & .941 & .044 & .057 & .210 & .082 & .043 & 1.000 & & \\
\hline $\begin{array}{l}\mathrm{BScE} \\
\mathrm{dFN}\end{array}$ & .316 & .138 & .068 & .077 & .039 & .913 & .035 & .133 & .085 & .051 & .109 & 1.000 & \\
\hline $\begin{array}{l}\text { BScE } \\
\text { dEM }\end{array}$ & .264 & .110 & .053 & .063 & .041 & .027 & .944 & .147 & .063 & .063 & .088 & .215 & 1.000 \\
\hline
\end{tabular}

Notes: $n=110$; significant: $p<.05 ;$ EN - Entrepreneurship Education; OP _ Operations

Research; NM - Numerical Methods for Partial Differential Equations; AN - Advanced 
Numerical Methods; FN - Functional Analysis; EM - Educational Management and Leadership; $M$ - Mean score; SD - Standard deviation

The results given in Table 6 show positive correlations at the 5\% level of significance between the entry requirements and academic performance. BScEd $\mathrm{EN}_{\mathrm{N}}$ $(\mathrm{r}=.473 ; \mathrm{p}<.05)$ had the highest correlation with AP, followed by B.Ed $\mathrm{EN}_{\mathrm{EN}}(\mathrm{r}=.454$; $\mathrm{p}<.05),{\mathrm{B} . E d_{\mathrm{NM}}}_{(\mathrm{r}=.351 ; \mathrm{p}<.05) \text { and BScEd }} \mathrm{NM}(\mathrm{r}=.346 ; \mathrm{p}<.05) . \operatorname{BScEd}_{\mathrm{AN}}(\mathrm{r}=$ $.207 ; \mathrm{p}<.05)$ had the least correlation with academic performance. With regard to inter-construct correlations, the results in Table 3 indicate that the highest correlations were between $\mathrm{BScEd} \mathrm{d}_{\mathrm{MT}}$ and $\mathrm{B} . \mathrm{Ed}_{\mathrm{EN}}(\mathrm{r}=.995 ; \mathrm{p}<.05)$, followed by the correlation between $\mathrm{BScEd}_{\mathrm{AN}}$ and B.Ed $\mathrm{AN}_{\mathrm{N}}(\mathrm{r}=.971 ; \mathrm{p}<.05), \mathrm{BSCEd}_{\mathrm{EM}}$ and B.Ed $\mathrm{EM}_{\mathrm{E}}$ $(\mathrm{r}=.944 ; \mathrm{p}<.05), \mathrm{BScEd}_{\mathrm{AN}}$ and B.Ed $\mathrm{AN}(\mathrm{r}=.941 ; \mathrm{p}<.05), \mathrm{BScEd}_{\mathrm{FN}}$ and B.Ed $\mathrm{EN}_{\mathrm{FN}}(\mathrm{r}=$ $.913 ; \mathrm{p}<.05)$, and $\mathrm{BScEd}_{\mathrm{BI}}$ and B.Ed $\mathrm{B}_{\mathrm{BI}}(\mathrm{r}=.902 ; \mathrm{p}<.05)$. These inter-correlations show that there is a very high likelihood of students with a B.Ed. entry qualification performing to the same level as those with a BScEd entry qualification in their areas of specialisation and vice versa. This further confirms the results provided in Table 3, indicating very little difference between the academic performance of students enrolled using their B.Ed. qualifications and those enrolled using their BScEd qualifications.

Table 7 shows the results of the test of association between academic performance and degree classification.

Table 7: One-way ANOVA on differences in academic performance based on degree classification

\begin{tabular}{llcccccc}
\hline $\begin{array}{l}\text { Degree } \\
\text { classification }\end{array}$ & Source & $\begin{array}{c}\text { Sum of } \\
\text { squares }\end{array}$ & Df & $\begin{array}{c}\text { Mean } \\
\text { square }\end{array}$ & $\mathrm{R}^{2}$ & $\mathrm{~F}$ & Sig. \\
\hline Distinction (D) & Between groups & 6.552 & 1 & 6.552 & .471 & 1.123 & .081 \\
$\mathrm{n}=27$ & Within groups & 151.705 & 25 & 5.835 & & & \\
& Total & 158.257 & 26 & & & & \\
Merit (M) & Between groups & 17.309 & 1 & 17.309 & .313 & 1.293 & .317 \\
$\mathrm{n}=40$ & Within groups & 508.541 & 38 & 13.383 & & & \\
& Total & 525.850 & 39 & & & & \\
Credit (C) & Between groups & 9.429 & 1 & 9.429 & .540 & 1.255 & .190 \\
$\mathrm{n}=31$ & Within groups & 217.825 & 29 & 7.511 & & & \\
& Total & 227.254 & 30 & & & & \\
Pass (P) & Between groups & 21.538 & 1 & 21.538 & .362 & .639 & .609 \\
$\mathrm{n}=12$ & Within groups & 337.118 & 10 & 33.712 & & & \\
& Total & & 11 & & & &
\end{tabular}

Notes: Significant: $p<.05 ; R^{2}$ - Coefficient of determination; $D f$ - Degree of freedom

The results depicted in Table 7 show that D (F.05; 1, $25=1.123 ; \mathrm{p}>.05) ; \mathrm{M}$ (F.05; $1,38=1.293 ; \mathrm{p}>.05) ; \mathrm{C}$ (F.05; 1, $29=1.255 ; \mathrm{p}>.05)$; and P (F.05; 1, $26=.639 ; \mathrm{p}>$ $.05)$. $\mathrm{H} 1$ was not supported. The results, therefore, show that degree classification does not contribute to significant differences between the academic performance of postgraduate students admitted to the M.Ed $\mathrm{MT}_{\mathrm{MT}}$ programme based on different degree classifications. The results also show that the Credit degree classification contributes the highest variation (54\%) to academic performance by $\mathrm{M}$.Ed $\mathrm{dT}_{\mathrm{MT}}$ students followed by the Distinction degree classification (47\%). The Merit degree classification contributes the least variation (31\%) to the academic performance of M.Ed $\mathrm{MT}_{\mathrm{T}}$ students. 
Table 8 provides the results of the test of the association between academic performance and the type of degree used for admittance into the M.Ed $\mathrm{MT}_{\mathrm{MT}}$ programme.

Table 8: Independent $t$-test on group academic performance based on degree type

\begin{tabular}{|c|c|c|c|c|c|c|}
\hline $\begin{array}{l}\text { Course } \\
\text { of study }\end{array}$ & $\begin{array}{l}\text { Entry } \\
\text { qualification }\end{array}$ & $\mathbf{N}$ & $\mathbf{M}$ & SD & tcalc-value & Decision \\
\hline \multirow[t]{2}{*}{ EN } & B.Ed ${ }_{M T}$ & 60 & 68.96 & 6.41 & 1.315 & Not Supported \\
\hline & $\mathrm{BScEd}_{\mathrm{MT}}$ & 50 & 71.61 & 8.08 & & \\
\hline \multirow[t]{2}{*}{ OP } & B.Ed $\mathrm{MT}_{\mathrm{MT}}$ & 60 & 70.59 & 10.16 & .501 & Not Supported \\
\hline & $\mathrm{BScEd}_{\mathrm{MT}}$ & 50 & 68.33 & 11.46 & & \\
\hline \multirow[t]{2}{*}{ NM } & B. $\mathrm{Ed}_{\mathrm{MT}}$ & 60 & 66.37 & 8.05 & 1.114 & Not Supported \\
\hline & $\mathrm{BScEd}_{\mathrm{MT}}$ & 50 & 64.53 & 8.31 & & \\
\hline \multirow[t]{2}{*}{ AN } & B.Ed $\mathrm{d}_{\mathrm{MT}}$ & 60 & 62.44 & 11.38 & 1.275 & Not Supported \\
\hline & $\mathrm{BScEd}_{\mathrm{MT}}$ & 50 & 61.57 & 9.61 & & \\
\hline \multirow[t]{2}{*}{ FN } & B.Ed $\mathrm{MT}_{\mathrm{MT}}$ & 60 & 65.19 & 10.27 & 1.741 & Not Supported \\
\hline & $\mathrm{BScEd}_{\mathrm{MT}}$ & 50 & 65.23 & 11.31 & & \\
\hline \multirow[t]{2}{*}{ EM } & B.Ed $\mathrm{ET}_{\mathrm{MT}}$ & 60 & 67.24 & 9.51 & 1.359 & Not Supported \\
\hline & $\mathrm{BScEd}_{\mathrm{MT}}$ & 50 & 67.52 & 10.58 & & \\
\hline
\end{tabular}

Notes: Expected t-value $=2.00 ;$ Significant: $p<.05 ; D f=106 ; \mathrm{N}-$ Number of students enrolled; $N$-Number of students in the course; $M$ - Mean score; SD - Standard deviation; tcalc-Calculated t-value

The results provided in Table 8 are the results of a test to determine whether there is a significant difference between the academic performance of students admitted to the M.Ed $\mathrm{MT}_{\text {MT }}$ programme based on the results of their B.Ed. and BScEd degrees. The results show that M.Ed $d_{\mathrm{EN}}$ (tcalc-value [1.315] < critical value [2.00]); M.EdoP (tcalc-value [.501] $<$ tcritical value [2.00]); M.Ed $_{\mathrm{NM}}$ (tcalc-value $[1.114]<$ tcritical value [2.00]), and $\mathrm{M} . E \mathrm{~d}_{\mathrm{AN}}$ (tcalc-value [1.275] < tcritical value [2.00]), M.Ed $\mathrm{FN}_{\mathrm{FN}}$

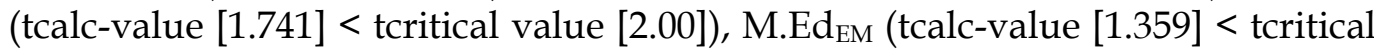
value [2.00]), hence $\mathrm{H} 0$ was accepted for all the hypotheses. These results, therefore, show that there was no significant difference between the academic performance of students admitted to all the M.Ed. programmes on the basis of their B.Ed. and BScEd as entry requirements.

\section{Discussion}

The purpose of the study was to establish whether enrolling students with different entry requirements contributes to significant differences in academic performance among postgraduate students. The study also sought to establish whether degree classifications contribute significantly to academic performance among students. The study used the Student Integration Model (SIM) developed by Tinto (1997) as a theoretical lens which showed that pre-programme admission attributes of students have a significant influence on their academic performance.

The results of the study showed that degree classification did not contribute significantly to academic performance differences among postgraduate students with different entry qualifications. This suggests that having high degree classifications does not necessarily lead to high academic performance as long as a student meets the basic requirements for admission to the post-graduate programme. Furthermore, the results also suggest that having a lower degree 
classification does not mean that a student will not achieve high grades in the postgraduate degree - of importance is complying with the minimum entry requirements. These results suggest that a student who is admitted to a postgraduate programme on the grounds of a distinction or merit degree classification in the undergraduate degree, will not perform significantly different in his or her postgraduate studies when compared to those students with either credits or just passes in their undergraduate degrees. The results of this study are therefore not consistent with the findings of previous studies, as well as with the idea of positive integration as articulated in the SIM by Tinto (1997). The SIM argues that pre-university or pre-programme attributes such as degree classification, have a significant influence on the academic performance of a student. Studies by Tatar and Düstegör (2020) Shahiri, Husain and Rashid (2017) and Putpuek et al. (2018) also established that degree classifications at entry level had a significant influence on the academic performance of students in their enrolled postgraduate programmes. Studies by Alamoudi et al. (2021), Kurlaender \& Cohen (2019), Abdullah and Mizra (2018), and Ferrão and Almeida (2019) further established that students with an A grade as either their preuniversity or pre-programme entry qualification had a very high likelihood of not only attaining high grades in their studies, but also of completing their studies. All these findings demonstrated the significant influence of degree classification on the academic performance of students. The main idea ensuing from these results, therefore, is that the usual assumptions that students admitted into programmes and courses with high degree classifications perform better than those with low degree classifications are not always correct.

It also emerged from the study that there were no significant differences in the academic performance of students admitted to the M.Ed $\mathrm{MT}_{\mathrm{MT}}$ programme on the basis of their B.Ed. and BScEd degrees. These results suggest that despite the differences in names of the entry programmes, students seemed to have been provided with the same academic background that gave them a solid foundation to be able to later perform academically to the same or almost the same level in the M.Ed $\mathrm{MT}_{\mathrm{T}}$ programme. The fact that the students who enrolled in the M.Ed $\mathrm{d}_{\mathrm{MT}}$ programme using the two different programmes, but scored general mean scores of around $60 \%$ in all M.Ed $\mathrm{MT}_{\mathrm{MT}}$ EOS examinations for the courses studied, showed that both entry programmes had provided the students with enough content depth to be able to perform at that level. This then suggests that it is not a question of what entry qualification students use to be admitted into the M.Ed $\mathrm{d}_{\mathrm{MT}}$ programmes but rather how relevant the entry qualifications are in terms of providing students with enough background information to be able to succeed in the postgraduate programmes. These results, therefore, are consistent with findings of earlier studies.

Separate studies by Abdulkadir et al. (2019), Queensoap et al. (2017), and Huntley et al. (2017) found no significant relationships between entry requirements and academic performance of students admitted to university programmes based on different entry requirements. These studies showed that if there were any differences between the academic performances of the students admitted into postgraduate programmes based on different entry requirements, such academic performance differences could be as a result of classroom size, learning 
environment, and age and gender of students, rather than entry requirements. The main idea resulting from these findings, therefore, is that those differences in the types of names of degrees do not affect the academic performance of students as long as such degrees meet the minimum requirements for students to be able to be admitted to the degree programme.

\section{Conclusions}

Based on the results discussed above, a number of conclusions were drawn. First, it was concluded that degree classifications of students in their undergraduate studies have no significant effect on their academic performance as postgraduate students. This means that having distinctions or just passes at undergraduate degree level cannot be used to determine whether students will perform better or not at postgraduate level. Second, it was concluded that being admitted into a postgraduate programme based on different entry requirements does not contribute to significant differences in the academic performance of postgraduate students. This conclusion implies that as long as the entry requirements are relevant to the postgraduate programme to be followed, a postgraduate student will perform almost to the same academic level as those who had different entry requirements.

\section{Recommendations}

The results of the study showed that students with different academic entry qualifications can perform at the same academic level at postgraduate level. It is therefore recommended that, for students to learn effectively, lecturers at universities should match their teaching approaches to the learning styles of the students. Universities also need to ensure that all the students have adequate learning materials and that the learning environment is conducive to teaching and learning, with manageable class sizes for all students admitted to the postgraduate programmes to be able to learn effectively and achieve more academically.

\section{Practical implications of the study}

The study has implications for both policy and practice with regard to the admission of postgraduate students with different entry requirements. In terms of policy, the implication of the study is that there is no need for strict entry requirements at postgraduate level, as students seem to perform at the same academic level, even with different entry requirements. With regard to practice, the findings of the study indicate that, if taught effectively, postgraduate students with different entry qualifications will perform to almost the same level academically.

\section{Limitations of the study}

The study was conducted on a small sample of universities. Future studies could attempt to validate the results by using a larger sample.

\section{Declarations}

Informed consent: Researcher obtained the consent of all participants before conducting the study. 
Ethics approval and consent to participate: The researchers got ethical approval from their respective university ethics board to conduct this study.

Availability of data and materials: Data were collected from academic records of the 2020 second semester. An entry-qualification academic-performance inventory was used to extract data on admissions and EOS examination results from the academic records of the four universities associated with this study.

Conflict of interest: The research has no conflict of interest to declare.

Funding: There is no funding to declare in this study.

Methods: The research methods used in this study were in line with relevant research guidelines and regulations for conducting ethical research.

\section{Acknowledgements}

The researchers wish to thank all students and their institutional management for participating in this study.

\section{References}

Abdullah, N., \& Mirza, M. (2018). Entry qualifications of students as predictors of academic performance in various degree programs in a distance education setting in Pakistan. Open Praxis, 10(3), 237-247.

Abdulkadir, S., Onibere, E. A., \& Odion, P. O. (2019). Assessment of Students' Academic Performance Using Admission Entry Requirements under the Computer-Based Test and Paper-Pencil-Based Test in Kaduna State University, Kaduna - Nigeria. International Journal of Modern Education and Computer Science, 8, 48-60.

Aciro, R., Onen, D., Malinga, G. M., Ezati, B. A., \& Openjuru, G. L. (2021). Entry Grades and the Academic Performance of University Students: A Review of Literature. Education Quarterly Reviews, 4(1), 141-150.

Adamu, M., Anza, A. I., \& Hananiya, P. (2019). Relationship between Entry Qualification and Students' Academic Achievement in Gombe State Tertiary Institutions. Nigeria. Specialty Journal of Knowledge Management, 4(4), 37-43.

Alamoudi, A. A., Fallatah, H. I., Eldakhakhny, B. M., Kamel, F. O., AlShawwa, L. A., \& Elsamanoudy, A. Z. (2021). Relationship between admission criteria and academic performance in basic science courses in health science colleges in KAU. BMC Medical Education (2021), 21(94), 1-8. https:/ / doi.org/10.1186/s12909-021-02502-4

Arnekrans, A. K. (2014). Tinto's Student Integration Model \& Diathesis Stress Model: Adverse Childhood Events, Resilience \& Retention in a First-Year University Population. [Doctor of Philosophy Degree in Counsellor Education \& Supervision]. University of Toledo.

Bindura University of Science Education. (2021). Admission requirements. https://www.buse.ac.zw/admissions/how-to-apply/

Brook, S., \& Roberts, M. (2021). What are the determinants of student performance on an undergraduate accounting degree? Journal of Further and Higher Education, 45(9), 1224-1239. http://doi.org/10.1080/0309877X.2021.1882666

Creswell, J. W. (2015). Educational research: Planning, conducting, and evaluating quantitative and qualitative research (5 $\left.5^{\text {th }} \mathrm{ed}\right)$. Boston, MA: Pearson.

Ferrão, M., \& Almeida, L. (2019). Differential effect of university entrance score on firstyear students' academic performance in Portugal. Assessment \& Evaluation in Higher Education, 44(4), 610-622.

Glen, S. (2016). Fmax / Hartley's Test: Definition, Step by Step Example, Table. Statistics How To.com: Elementary Statistics for the rest of us! https://www.statisticshowto.com/fmax-hartleys-test/ 
Great Zimbabwe University. (2021). Entry requirements. https://www.eafinder.com/listof-postgraduate-courses-offered-at-gzu-2020-2021/

Haj, C. M., Geanta, I. M., \& Orr, D. (2018). A Typology of Admission Systems Across Europe and Their Impact on the Equity of Access, Progression and Completion in Higher Education. In: Curaj A., Deca L. \& Pricopie R. (Eds). European Higher Education Area: The Impact of Past and Future Policies. Springer, Cham. https://doi.org/10.1007/978-3-319-77407-7_12

Ihiegbulem, T. O. (1992). Academic Performance of Nigeria Certfcate in Educaton (Technical) Students, with Diferent Entry Requirements: A Case Study of Federal College of Educaton (Technical), Omoku, Rivers State. Journal of Technical Teacher Educaton, 1(1), 79-86.

Kpolovie, P. J. (2020). Advanced Research Methods. Owerri: Springfield Publishers.

Kurlaender, M., \& Cohen, K. (2019). Predicting College Success: How Do Different High School Assessments Measure Up? Policy Analysis for California Education, PACE.

Ministry of Higher and Tertiary Education, Innovation, Science and Technology Development. (2021). Universities recommit to STEM mandates. http://www.mhtestd.gov.zw/?page_id=3588

Murray, M. (2017). Exploring the relationship between entry requirements and throughput rates for honours students. South African Journal of Science, 113(9/10), 1-6. http://dx.doi.org/10.17159/ sajs.2017/20160281

Mutiso, S. K., \& Muthama, T. M. (2019). Determinants of Academic Performance for Undergraduate Students in Kenya: An Educational Production Approach. IOSR Journal Of Humanities And Social Science (IOSR-JHSS), 24(3).

Odukoya, J. A., Adekeye, O. A., Atayero, A. A., Omole, D. O., Badejo, J. A., Temitope, J. M., \& Popoola, S. I. (2018). The Predictive Validity of University Admission Examinations: Case Study of Nigerian Unified Tertiary Matriculation Examination. Covenant International Journal of Psychology (CIJP), 3(1), 1-10.

Olubusayo, A. A. (2021). Entry qualifications and academic performance of teacher trainees in Lagos State Colleges of Education: Implications for counselling. Babcock University Journal of Education (BUJED), 7(1), 15-28.

Phillips, P. C. B. (1982). The true characteristic function of the F distribution. Biometrika, 69, 261-264.

Putpuek, N., Rojanaprasert, N., Atchariyachanvanich, K., \& Thamrongthanyawong, T. (2018). Comparative Study of Prediction Models for Final GPA Score: A Case Study of Rajabhat Rajanagarindra University. IEEE/ACIS 17th International Conference on Computer and Information Science, (pp. 92-97).

Queensoap, M., Arogo, N. I., Dogitimiye, M., Williams, D. O., \& Maxwell, D. J. (2017). The Use of Entry Grades to Predict Bayelsa State Students' Academic Success at College of Health Technology, Ogbia. International Journal of Education and Evaluation, 3(9), 75-84.

Shahiri, A. M., Husain, W., \& Rashid, N. A. (2015). A review on predicting students' performance using data mining techniques. Procedia Computer Science, 72, 414-422.

Sharma, S. (2019). A Quantitative Ex-Post-Facto Study for one-to-one mobile technology. https://www.researchgate.net/publication/333220493_Experimental_and_Ex_P ost_Facto_Designs

Schreiber, B., Luescher-Mamashela, T., \& Moja, T. (2014). Tinto in South Africa: Student integration, persistence and success, and the role of student affairs. Journal of Student Affairs in Africa, 2(2), 1-6.

Sulphey, M. M, AlKahtani, N. S., \& Syed, A. M. (2018). Relationship between admission grades and academic achievement. Entrepreneurship and Sustainability Issues, 5(3), 648-658. http://doi.org/10.9770/jesi.2018.5.3(17) 
Tatar, A. E., \& Düstegör, D. (2020). Prediction of Academic Performance at Undergraduate Graduation: Course Grades or Grade Point Average? Applied Sciences, 10, 1-15.

The Research Advisors. (2006). Sample size table. http://research advisors.com/index.php

Tinto, V. (1997). Classrooms as communities: Exploring the educational character of student persistence. Journal of Higher Education, 68(6), 599-623.

University of Zimbabwe. (2019). Entry requirements. https://www.uz.ac.zw/index.php/admissions/post-application-overview

Wambugu, L. N., \& Emeke, E. A. (2016). Relationship between Entry Qualification and Academic Performance in Undergraduate Science Courses at the University of Nairobi, Kenya [Paper presentation]. Third International Conference of the African Virtual University (AVU) on Integrating Mobile Learning to Open up Access to Quality Education and Training Opportunities in Africa, Kenya.

Wang, X., \& Kattan, M. W. (2020). Cohort Studies Design, Analysis, and Reporting. CHEST, 158(1S), 72-78.

Watson, C. A. (2021). An Ex Post Facto Study on the Relationship Between Self-Reported Peer-to-Peer Mentoring Experiences and Instructor Confidence, Institutional Loyalty, and Student Satisfaction among Part-Time Instructors [Dissertations]. Andrews University. https://digitalcommons.andrews.edu/dissertations/1529 